38. The liver sample of patient $M N$ was obtained by the courtesy of Professor L. S. Prod'hom.

39. MSE, London, England.

40. The skin biopsies were obtained with the informed consent of the parents of the patient and control subjects. We are grateful to Dr. Erika Buihler for the cultivation of the fibroblasts and to Dr. Uirich Wiesmann, Bern, for providing us with additional control fibroblasts.

41. We wish to thank Dr. W. L. Nyhan for making available fibroblasts of patient $C E$ to us.

42. Difco, Detroit, Mich.

43. Gibco, Grand Island, N.Y.

44. Propionyl-CoA was prepared from propionic anhydride and coenzyme A (11). Its purity was confirmed by ascending chromatography of its hydroxamic acid derivative in water-saturated butanol (32). The concentration of propionyl-CoA was measured by its reaction with hydroxylamine (22) and by titration of the - $\mathrm{SH}$ groups before and after hydrolysis by the nitroprusside method of Grunert and Phillips (13)

45. Ciba-Geigy, Basel, Switzerland.

46. We acknowledge the skillful technical assistance of $\mathrm{L}$. Katajasaari and $\mathrm{N}$. Pollaert.

47. Requests for reprints should be addressed to: E. R. Baumgartner, M.D., University Children's Hospital, Römergasse 8, 4000 Basel, Switzerland.

48. Accepted for publication March 10, 1975.

\title{
Growth and Mineral Metabolism in Very Low Birth Weight Infants. I. Comparison of the Effects of Two Modes of $\mathrm{NaHCO}_{3}$ Treatment of Late Metabolic Acidosis
}

\author{
I. C. RADDE, ${ }^{(34)}$ G. W. CHANCE, K. BAILEY, J. O'BRIEN, G. M. DAY, AND J. SHEEPERS \\ Research Institute, the Hospital for Sick Children, Divisions of Neonatology and Endocrinology; Department of \\ Paediatrics, University of Toronto, Toronto, Canada
}

\section{Extract}

Twenty-six infants weighing less than $1,300 \mathrm{~g}$ at birth were divided into pairs according to birth weight $(900-1,100$ and $1,101-1,300 \mathrm{~g}$ ) and gestational age ("appropriate" (AGA) = mean 31 weeks; and "small" (SGA) = mean 34 weeks). One member of the pairs was then allocated randomly to one of two treatment regimens with oral sodium bicarbonate. Group $A$ was treated whenever base excess was greater than $-8 \mathrm{mEq}$ /liter as detected on twice weekly testing and/or when suspected to be acidotic from failure to gain weight. In group $B$, base excess was maintained within $1 \mathrm{SD}$ of normal $(-3.2 \pm 1.7 \mathrm{mEq} / \mathrm{liter})$. The infants received Enfalac $200 \mathrm{ml} / \mathrm{kg} / 24 \mathrm{hr}$, at $67 \mathrm{cal} / 100 \mathrm{ml}$, with vitamin D 400 IU $/ 24 \mathrm{hr}$ added from age 2 weeks.

The following measurements were made: daily weight, weekly length, skinfold thickness, head circumference, twice weekly blood $\mathrm{pH}, \mathrm{PaCO}_{2}$, base excess, and weekly plasma total calcium, ionic calcium, total magnesium, inorganic phosphorus, and total protein.

There were six pairs each of AGA and SGA infants and two unpaired group $A$ infants. Weekly weight gains did not differ between group $A$ and group $B$ or between AGA and SGA. Length increment was greater in AGA than in SGA babies $(0.94 \pm 0.02$ vs $0.85 \pm 0.04 \mathrm{~cm} /$ week $)$ but not significantly so $(P<0.1)$, and in group $B$ babies compared to group $A$ babies $(0.973 \pm 0.029$ vs 0.83 $\pm 0.037 \mathrm{~cm} /$ week $)(P<0.01)$.

Plasma $\mathrm{pH}$ was lower in group $A(7.23 \pm \mathbf{0 . 0 2})$ than in group $B$ $(7.30 \pm \mathbf{0 . 0 2})$ and calcium ion activity higher (group $A$ 2.72 $\pm \mathbf{0 . 0 4}$; group $B \quad 2.51 \pm 0.06 \mathrm{mEq} /$ liter) between ages 20 and 29 days. Plasma magnesium was higher in group $A(1.77 \pm 0.04 \mathrm{mEq} /$ liter $)$ than in group $B(1.56 \pm 0.06 \mathrm{mEq} /$ liter $)$ from age 20 to 39 days. Inorganic phosphorus concentrations were consistently higher in group $A$ than in group $B$, but the differences did not reach significance. Mean total protein concentrations did not rise above $4.5 \mathrm{~g} / 100 \mathrm{ml}$ and tended to be higher in babies of group $A$ than of group $B$.
Bone age was retarded in all babies. Radiographs available for 7 of 13 SGA infants were normal, whereas 6 of 11 radiographs of AGA babies showed some osteoporotic changes.

\section{Speculation}

Careful control of late metabolic acidosis in infants $<1.3 \mathrm{~kg}$ birth weight results in less ionic hypercalcemia and improved growth in length. In the more immature AGA infants, radiologic osteoporosis was seen. Mineral and protein content of formula currently used for feeding infants of less than $1,300 \mathrm{~g}$ birth weight is inappropriate to their requirements for growth.

Late metabolic acidosis as defined by Kildeberg (12) is common in very low birth weight (VLBW) $(<1.3 \mathrm{~kg})$ infants (22), and the condition may require intermittent correction for several months (18).

Unless corrected, one of the adverse consequences of late metabolic acidosis is said to be failure to gain weight (12). Acidosis may inhibit bone mineralization $(4,14)$, lead to hypercalcemia (ionic fraction), hypercalciuria (23), and may even be associated with reduced rates of skeletal growth (5). These potential complications might be aggravated by routine administration of vitamin $\mathrm{D}$ in doses unrelated to body weight as was recently recommended for the prevention of rickets in these infants (15).

Since the survival rate of VLBW infants is increasing, we consider it important to study the effects of acidosis on their growth and mineral homeostasis. The purpose of this initial study was to compare the influence of two treatment regimens for late metabolic acidosis in infants pair-matched for birth weight and gestational age. We assessed the influence of the regimens on body and skeletal growth and on mineral homeostasis. We hoped to favor bone mineralization by strict maintenance of normal acidbase balance. 
In a companion paper (7) we have further examined the effect of calcium supplementation on various aspects of mineral homeostasis and growth while the infants' negative base excess was strictly maintained in the normal range.

\section{PATIENTS AND PROCEDURES GROUPING}

Thirty infants, 14 days old, whose birth weight was less than 1.3 $\mathrm{kg}$ and whose $\mathrm{P}_{\mathrm{CO} 2}$ was persistently $<50 \mathrm{~mm} \mathrm{Hg}$ entered the study. Infants whose $\mathrm{P}_{\mathrm{CO} 2}$ was persistently $>50 \mathrm{~mm} \mathrm{Hg}$ or who developed unrelated complications (four infants) had to be excluded. The age of 14 days was chosen because the infants had then overcome problems of initial adaptation and their formula intake was $>80 \%$ of the desired amount. Gestational age was assessed using the criteria of Dubowitz et al. (8). The basis for pairing according to birth weight was within the range of $900-1,100 \mathrm{~g}$ (three pairs) and 1,101-1,300 g (nine pairs). Six pairs were AGA (>3rd centile (26)), and six pairs were SGA. There was, in addition, one infant in each of these categories who could not be paired during the study but whose growth and plasma chemical measurements were recorded.

One member of each pair was randomly assigned to group $A$ and was treated by our usual bicarbonate regimen, i.e., given $\mathrm{NaHCO}_{3}$ with feedings for $48 \mathrm{hr}$ whenever weight gain ceased for $48 \mathrm{hr}$ and the negative base excess was $-8 \mathrm{mEq} /$ liter or greater, or if this value was found on the routine twice weekly monitoring. The dose of bicarbonate in $\mathrm{mEq} / 24 \mathrm{hr}$ was administered according to the formula: body weight (kilograms) $\times 0.6 \times$ base deficit (milliequivalents per liter) and was adjusted on the basis of measurements on arterialized capillary blood obtained by heel prick. The other member of the pair, assigned to group $B$, was maintained in normal acid-base equilibrium by a dose of bicarbonate one-third that used in group $A$, given if base excess estimations at the twice weekly testing exceeded $-4.9 \mathrm{mEq} /$ liter (normal mean $\pm 1 \mathrm{SD}=3.2 \pm 1.7 \mathrm{mEq} /$ liter $)(1)$.

The infants were maintained in a controlled thermal environment until they weighed approximately $1.8 \mathrm{~kg}$ when they were removed from the incubators. All were fed $200 \mathrm{ml} / \mathrm{kg}$ body weight $/ 24 \mathrm{hr}$ of Enfalac, $20 \mathrm{cal}(67 \mathrm{cal} / 100 \mathrm{ml})(30)$ at 2-hourly intervals until $1,500 \mathrm{~g}$ and 3-hourly intervals thereafter until the end of the study. Vitamin $D_{2}, 400$ IU daily, was given as Tri-Vi-Sol (30) from age 14 days when the infants entered the study.

\section{PROCEDURES}

Each infant was weighed at the same time each day by one of two observers using an Air-Shields balance (31) and a highly standardized technique. Each week, head circumference was noted and body length measured making use of tonic neck reflexes as described by Miller and Hassanein (19). Duplicate measurements of skinfold thickness also were made weekly with Harpen- den calipers at each of three sites: triceps, subscapular, and paraumbilical regions.

Once a week, $0.8 \mathrm{ml}$ venous blood was obtained in lightly heparinized syringes (2l) for determination of $\mathrm{pH}$ and plasma concentrations of total calcium, calcium ion activity, total magnesium, inorganic phosphorus, and total protein. Body size measurements and weekly monitoring of chemical values were carried out until the infant's weight had reached $2,000 \mathrm{~g}$, at which time the study terminated.

When the infant was 2 months old, or weighed $2,000 \mathrm{~g}$, a radiograph of knees and hands was made to assess rachitic or osteoporotic changes and skeletal maturation. The radiographs were evaluated by the same senior radiologist without knowledge of to which group the infant belonged.

\section{CHEMICAL METHODS}

Blood $\mathrm{P}_{\mathrm{CO} 2}$ and $\mathrm{pH}$ were determined with a $\mathrm{pH}$ and blood gas analyzer $(20)$ and the base excess computed from a SiggaardAndersen chart (25).

Ionic calcium in plasma was determined under anaerobic conditions with a $\mathrm{Ca}^{++}$flow-through system and digital $\mathrm{pH}$ meter (21). Total $\mathrm{Ca}$ and $\mathrm{Mg}$ concentrations were measured by emission and atomic absorption flame spectrophotometry $(2,17)$. Inorganic phosphorus was measured by the Gomori method (10) and total plasma protein concentrations by the method of Lowry et al. (16), both adapted to the AutoAnalyzer.

\section{RESULTS}

\section{BODY WEIGHT}

The body weights of each pair were compared sequentially in two ways: $(I)$ by plotting weights in absolute figures on standard neonatal charts $(6,26)$, and $(2)$ by plotting them on a sequential paired analysis grid (3). The infants had usually returned to their birth weight by the first 15-20 days of life. Subsequently, most infants' weight curves were parallel to the third centile intrauterine weight curve (26). On the graph designed by Dancis et al. (6), the weights of four infants (two AGA, two SGA) crossed the next lower line; the weight graphs of the remaining infants usually ran parallel to these weight lines. Neither birth weight nor daily weight gain in grams differed between group $A$ and $B$ or between AGA and SGA infants (Table 1).

\section{BODY LENGTH AND HEAD CIRCUMFERENCE}

The length gain (centimeters per week) was significantly greater in group $B$ babies than in group $A$ babies when results from AGA and SGA infants were pooled $(P<0.02)$. Comparison of paired data showed a highly significant difference between groups $A$ and $B$ babies in the SGA group $(P<0.01)$ (Fig. 1) if one pair was excluded whose group $B$ member had a markedly foreshortened

Table 1. Patient data ${ }^{2}$

\begin{tabular}{|c|c|c|c|c|c|c|}
\hline & \multicolumn{3}{|c|}{$\mathrm{AGA}$} & \multicolumn{3}{|c|}{ SGA } \\
\hline & Group $A$ & & Group B & Group $A$ & & Group B \\
\hline Birth weight $(\mathrm{g})^{2}$ & $1,200 \pm 26$ & & $1,186 \pm 38$ & $1,125 \pm 63$ & & $1,146 \pm 58$ \\
\hline \multicolumn{7}{|l|}{ Gestational age (weeks) } \\
\hline Range & $30-32$ & & $29-32$ & $31.5-35$ & & $31-36$ \\
\hline $\begin{array}{l}\text { Skinfold thickness increment } \\
(\mathrm{cm} / \text { week })^{2}\end{array}$ & $0.27 \pm 0.04$ & & $0.32 \pm 0.08$ & $0.40 \pm 0.04$ & & $0.27 \pm 0.08$ \\
\hline
\end{tabular}

${ }^{1} \mathrm{AGA}$ : appropriate for gestational age; SGA: small for gestational age.

${ }^{2}$ Mean \pm SEM. 
thoracolumbar spine because of severe vertebral anomaly. The difference between group $A$ and $B$ in AGA babies just failed to reach significance $(P<0.10)$ (Fig. 1). Group comparisons in body length between AGA and SGA babies showed no significant difference in length gain $(P<0.10)$.

Head circumference increments were similar in all patients, the average being similar to the $3 \mathrm{rd}$ centile value of Usher and McLean (26).

\section{SKINFOLD THICKNESS}

The average increments of skinfold thickness for groups $A$ and $B$ did not differ. For SGA babies in group $A$ the increment was greater than in group $B(P<0.05)$ (Table 1$)$.

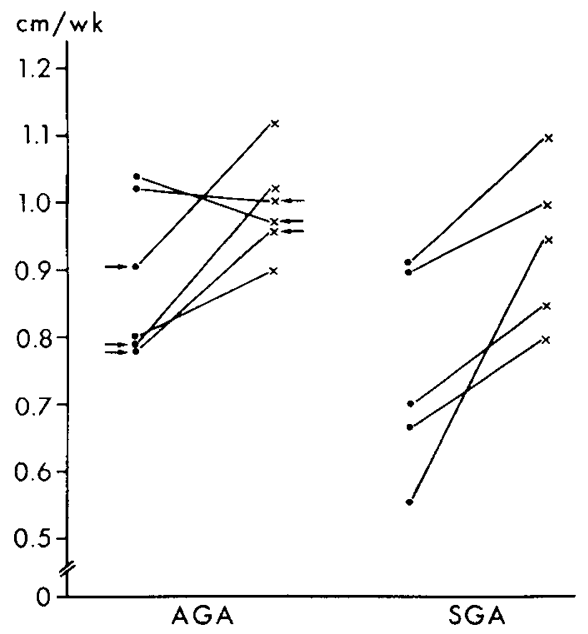

Fig. 1. Weekly length increments (centimeters per week) of infants of groups $A(\bullet)$ and $B(\times)$. For purposes of comparison, values for each pair of infants are connected. Results have been grouped according to weight for gestational age. $A G A$ : appropriate for gestational age; SGA: small for gestational age. Arrows indicate patients with osteoporosis on radiographs.

\section{BLOOD AND PLASMA CHEMICAL VALUES}

Because no significant differences occurred between results in AGA and SGA infants, all chemical values were grouped for analysis according to postnatal age and groups $A$ and $B$ (Table 2). Baseline values were obtained between ages 14 and 19 days before instituting specific bicarbonate regimens. Subsequent values were pooled in 10-day periods and the group means obtained.

Blood $p H$ and $P_{\mathrm{CO}_{2}}$. Infants in group $A$ required bicarbonate treatment for an average of 3 days, whereas those of group $B$ were treated for a mean of 16 days.

In both patient groups the $\mathrm{pH}$ rose slightly from the age of 14-19 days to the end of the observation period at 7 weeks of age or older. Significant differences between the two groups were seen only at the 20-29-day period with infants of group $A$ having a lower $\mathrm{pH}$ than infants of group $B(P<0.01)$.

The $P_{\mathrm{CO}_{2}}$ of patients in group $A$ declined gradually from 50 to 1 $\mathrm{mm} \mathrm{Hg}$, whereas in patients of group $B$ the change was inconsistent.

Plasma Calcium (Ionized and Total). Mean ionic calcium values did not change significantly although calcium ion activity in plasma varied in individual patients during the observation period. However, ionic calcium values in group $A$ were significantly elevated compared with those in group $B$ babies during the period of significant acidosis (20-29 days of age). During the ages of 20-49 days approximately $20-30 \%$ of ionic calcium values in both groups were above $2.70 \mathrm{mEq} /$ liter $(>2 \mathrm{SD}$ above normal mean of $2.50 \mathrm{mEq} /$ liter). In infants older than 50 days ionic hypercalcemia became less frequent. Total calcium concentrations in plasma were significantly higher during the first 16 days than during the rest of the period of study.

Plasma Magnesium, Inorganic Phosphorus, and Protein Concentrations. Mean plasma magnesium concentrations were lower in group $B$ than in group $A$ and showed a tendency to rise during the study, but this trend did not reach significance. Between 20 and 39 days, group $A$ showed significantly higher values than group $B$.

Inorganic phosphorus concentrations decreased progressively

Table 2. Chemical values in blood and plasma in very low birth weight infants, mean $\pm S E M(n)$

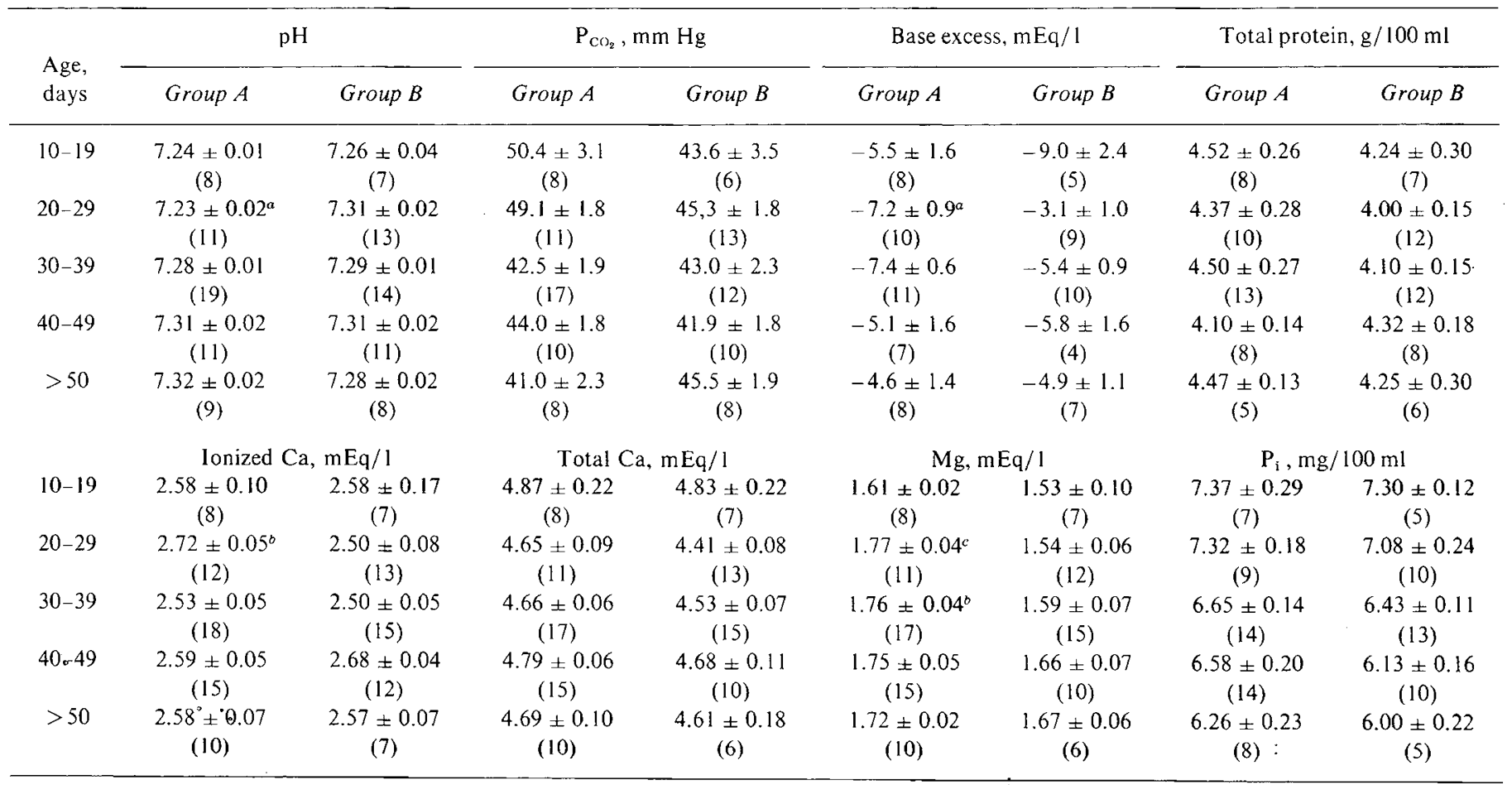

${ }^{a} P<0.01$.

${ }^{\circ} P<0.05$.

${ }^{c} P<0.005$. 
with increasing age in both groups from an initial mean of 7.3 to $6.2 \mathrm{mg} / 100 \mathrm{ml}$. At all times, inorganic phosphorus concentrations were higher in group $A$ than in group $B$ patients, but differences were not significant.

\section{RADIOGRAPHS OF HANDS AND KNEES}

At the end of the study, of the 11 available radiographs of AGA babies 6 showed mild to moderate changes indicative of osteoporosis, and in 1 of the signs of osteomalacia were also noted. Bone density was normal in the remaining AGA babies but skeletal maturation was retarded. Radiographs were obtained in only 7 of the 13 SGA infants; all showed normal bone density, although skeletal maturation was also retarded.

\section{DISCUSSION}

Late metabolic acidosis develops in premature infants weighing $<1.3 \mathrm{~kg}$ at birth for several reasons, one of them being liberation of hydrogen ions from bone during mineralization (13). The postnatal period during which we studied these VLBW infants corresponded to the time in utero when the rate of bone mineralization would have been maximal $(24,29)$.

Our results show that when acid-base normality is maintained within $1 \mathrm{SD}$ of normal $(-3.2 \pm 1.7 \mathrm{mEq} /$ liter $)$, the elevated plasma ionic calcium values are better controlled, and length gain is significantly increased (a 15\% increase in growth rate and equivalent to $1 \mathrm{~cm}$ in 50 days). SGA infants are recognized to have a reduced growth potential (8). In our study, SGA infants maintained in strict acid-base equilibrium grew at a rate comparable with AGA infants whose metabolic acidosis was treated only intermittently, as well as with AGA infants whose acid-base equilibrium was strictly maintained.

West and Smith (27) have shown that the acidosis in chronic renal disease may be an important factor in reducing the growth rate. Cooke et al. (5), in a well controlied study in pair-fed rats, also found reduced skeletal growth when the animals were made acidotic with $\mathrm{NH}_{4} \mathrm{Cl}$ and acetazolamide. Strict maintenance of acid-base equilibrium may thus potentiate growth toward the intrauterine rate.

The greater length gain in group $B$ was achieved without obesity, as compared with group $A$, the weight increments being the same and skinfold increments being less. The SGA babies were more mature, and three of group $A$ grew less well but became more adipose than those of group $B$.

Harrison and Peat (11) suggested that addition of $\mathrm{NaHCO}_{3}$ to milk to alter titratable acidity led to improved weight gain because of reduced bacterial growth in the gut. Such a mechanism was not operative in our study since there was no difference in weight gain between groups.

Osteoporosis was observed only in AGA infants. The shorter gestational period of AGA babies may have been a factor contributing to its development because de facto the total body calcium content must have been approximately $4.5 \mathrm{~g}$ less (28) $(=$ $80 \%$ of their total body stores when these infants entered the study). Even with $100 \%$ absorption the relatively low calcium content of the formula used (approximately $50 \mathrm{mg} / 100 \mathrm{ml}$ ) prevented adequate mineralization of their bones. Hypoproteinemia was probably not a major factor in the development of osteoporosis since plasma protein concentrations were similar in AGA and SGA babies and only the former developed osteoporosis.

The finding of abnormally high ionic $\mathrm{Ca}^{++}$in $30 \%$ of patients in the presence of high inorganic phosphorus in plasma in VLBW is cause for concern, especially when the recommended dose of vitamin $D$ is used. We had originally considered that such relatively high ionic calcium levels observed in the plasma of many very low birth weight babies were related to vitamin $\mathrm{D}$ overdosage. The fact that ionized calcium in plasma decreases with strict maintenance of acid-base normality is potentially important.

\section{SUMMARY}

Two groups of very low birth weight infants $(<1.3 \mathrm{~kg})$ were compared as to their growth pattern and mineral retention. The infants in the control group received an intermittent correction of metabolic acidosis with $\mathrm{NaHCO}_{3}$, when their base excess was greater than $-8 \mathrm{mEq} /$ liter. The second group of infants were given sufficient $\mathrm{NaHCO}_{3}$ to maintain their base excess strictly within 1 $\mathrm{SD}$ of normal $(-2.3 \pm 1.7 \mathrm{mEq} /$ liter $)$.

Strict maintenance of acid-base homeostasis was associated with greater length increments than observed in the control group, although weight gains between groups did not differ. Ionic hypercalcemia was observed less frequently in babies whose acidosis was more strictly controlled than in the control infants. Osteoporosis was a feature in AGA babies but was not seen in SGA babies and was thus related to gestational age.

We advocate the strict maintenance of acid-base homeostasis within $1 \mathrm{SD}$ of normal in VLBW infants.

\section{REFERENCES AND NOTES}

1. Albert, M. S., and Winters, R. W.: Acid-base equilibrium of blood in normal infants. Pediatrics, 37: 728 (1966).

2. Alcock, N., MacIntyre, I., and Radde, I.: The determination of magnesium in biological fluids and tissues by flame spectrophotometry. J. Clin. Pathol., 13: 506 (1960).

3. Armitage, P.: Sequential Medical Trials (Charles C Thomas, Springfield, Ill., 1960).

4. Barzel, U. S., and Jowsey, J.: The effects of chronic acid and alkali administration on bone turnover in adult rats. Clin. Sci., 36: 517 (1969).

5. Cooke, R. E., Boyden, D. G., and Haller, E.: The relationship of acidosis and growth retardation. J. Pediat., 57: 326 (1960).

6. Dancis, J., O'Connell, J. R., and Holt, L. E., Jr.: A grid for recording the weight of premature infants. J. Pediat., 33: 570 (1948).

7. Day, G. M., Chance, G. W., Radde, I. C., Reilly, B. J., Park, E., and Sheepers, J.: Growth and mineral metabolism in very low birth weight infants. II. Effects of calcium supplementation on growth and divalent cations. Pediat. Res., 9: 000 (1975).

8. Dubowitz, L. M. S., Dubowitz, V., and Goldberg, C.: Clinical assessment of gestational age in the newborn infants. J. Pediat., 77: 1 (1970).

9. Fitzhardinge, P. M., and Steven, E. M.: The small-for-date infant. I. Later growth patterns. Pediatrics, 49:671 (1972).

10. Gomori, G.: A modification of the colorimetric phosphorus determination for use with the photoelectric colorimeter. J. Lab. Clin. Med., 27:955 (1942).

11. Harrison, V. C., and Peat, G.: Significance of milk pH in newborn infants. Brit. Med. J., 4: 515 (1972).

12. Kildeberg, P.: Disturbances of hydrogen ion balance occurring in premature infants. II. Late metabolic acidosis. Acta Pediat. Scand., 53: 517 (1964).

13. Kildeberg, P.: Clinical Acid-Base Physiology: Studies in Neonates, Infants and Young Children (The Williams \& Wilkins Co., Baltimore, 1968).

14. Lemann, J., Jr., Litzow, J. R., and Lennon, E. J.: The effects of chronic acid loads in normal man: Further evidence for the participation of bone mineral in the defence against chronic metabolic acidosis. J. Clin. Invest., 45: 1608 (1966).

15. Lewin, P. K., Reid, M., Reilly, B. J., Swyer, P. R., and Fraser, D.: Iatrogenic rickets in low-birthweight infants. J. Pediat. 78: 207 (1971).

16. Lowry, O. H., Rosebrough, N. J., Farr, A. L., and Randall, R. J.: Protein measurement with the Folin phenol reagent. J. Biol. Chem., 193: 265 (1951).

17. MacIntyre, I.: Flame photometry. Advan. Clin. Chem., 4: 1 (1961)

18. Manzke, H., and Nolte, H.: Untersuchungen des Säure-Basen-Status bei Frïhgeborenen. Z. Kinderheilk. 102: 250 (1968).

19. Miller, H. C., and Hassanein, K.: Diagnosis of impaired fetal growth in newborn infants. Pediatrics, 48: 511 (1971).

20. Owen-Thomas, J. B., Ulan, O. A., and Swyer, P. R.: The effect of varying inspiratory gas flow rate on arterial oxygenation during IPPV in the respiratory distress syndrome. Brit. J. Anaesthesiol., 40: 493 (1968).

21. Radde, I. C., Horfken, B., Parkinson, D. K., Sheepers, J., and Luckham, A.: Practical aspects of a measurement technique for calcium ion activity in plasma. Clin. Chem., 17: 1003 (1971).

22. Ranløv, P., and Siggaard-Andersen, O.: Late metabolic acidosis in premature infants: Prevalence and significance. Acta Paediat. Scand., 54: 531 (1965).

23. Reidenberg, M. M., Haag, B. L., Channick, B. J., Shuman, C. R., and Wilson, T. G. G.: The response of bone to metabolic acidosis in man. Metabolism, 15: 236 (1966).

24. Shaw, J. C. L. L.: Parenteral nutrition in the management of sick low birth weight infants. Pediat. Clin. N. Amer., 20: 333, (1973).

25. Siggaard-Andersen, O., Engel, K., Jorgensen, K., and Astrup, P.: A micromethod for determination of $\mathrm{pH}$, carbon dioxide tension, base excess and standard bicarbonate in capillary blood. Scand, J. Clin. Lab. Invest. I2: 172 (1960).

26. Usher, $\mathrm{R}$, and McLean, $\mathrm{F}$. Intrauterine growth of live-born Caucasian infants at sea level: Standards obtained between measurements in 7 dimensions of infants born between 25 and 44 weeks gestation. J. Pediat., 74: 901 (1969). 
27. West, C. D., and Smith, W. C.: An attempt to elucidate the cause of growth retardation in renal disease. Amer. J. Dis. Child., 91: 460 (1956).

28. Widdowson, E. M.: Biology of gestation. In: N. S. Assali: The Fetus and Neonate, Vol II (Academic Press, New York, 1968).

29. Widdowson, E. M., and Spray, C. M.: Chemical development in utero. Arch. Dis Childhood, 26: 205 (1951).

30. Mead Johnson Laboratories, Toronto, Ontario, Canada.

31. Air-Shields (Canada) Ltd., Downsview, Ontario, Canada.

32. The authors wish to thank Dr. B. J. Reilly, Chief of Radiology, The Hospital for Sick Children, for the interpretation of radiographs; Mrs. B. Woode, R.N., for her assistance in caring for the babies; Mrs. D. Hanimyan, B. Sc., Mr. J. Fabenyi, B. Agr, and Mr. M. Kahn for their expert technical assistance. The authors are grateful to the Medical and Nursing Staff of the Neonatal Unit of the Hospital for Sick Children for their help and cooperation.

33. This research was supported in part by the Medical Research Council, Canada, Grant MA 4635.

34. Requests for reprints should be addressed to: I. C. Radde, M.D., Research Institute, The Hospital for Sick Children, 555 University Ave., Toronto 2, Ontario (Canada).

35. Accepted for publication July 31, 1974.

\title{
Growth and Mineral Metabolism in Very Low Birth Weight Infants. II. Effects of Calcium Supplementation on Growth and Divalent Cations
}

\author{
G. M. DAY, G. W. CHANCE, I. C. RADDE, (49) B. J. REILLY, E. PARK, AND J. SHEEPERS \\ Research Institute, The Hospital for Sick Children, Divisions of Neonatology and Endocrinology; Department of \\ Paediatrics, University of Toronto, Toronto, Canada
}

\section{Extract}

Infants of two groups, one of 16 , one of 14 infants, who weighed $<1.3 \mathrm{~kg}$ at birth (mean $1.01 \pm 0.05 \mathrm{~kg}$ ), were studied from age 14 days until they reached $1.8 \mathrm{~kg}$ body weight. Infants were pairmatched for gestational age and birth weight and one member was randomly allocated to two treatment groups. Infants in group $A$ received no calcium supplement and those in group $B$ received calcium lactate, $800 \mathrm{mg} / \mathrm{kg} / 24 \mathrm{hr}$, in divided doses with each feed. All were fed "Improved" SMA, $200 \mathrm{ml} / \mathrm{kg} / 24 \mathrm{hr}, 160 \mathrm{cal} / \mathrm{kg} / 24 \mathrm{hr}$, and were given a multivitamin preparation containing 500 IU vitamin $\mathrm{D}_{2} /$ dose.

The infants' weekly length gain did not differ between groups $(1.08 \pm 0.04 \mathrm{~cm} /$ week $v s 1.11 \pm 0.04 \mathrm{~cm} /$ week; mean \pm SEM $)$. Mean weight and head cercumference increments also were similar (group $A, 163 \pm 6 \mathrm{~g} /$ week; $1.12 \pm 0.03 \mathrm{~cm} /$ week; group $B, 170 \pm$ $6 \mathrm{~g} /$ week and $1.18 \pm 0.03 \mathrm{~cm} /$ week $)$.

An increase in blood $\mathrm{pH}$ from $7.33 \pm 0.01$ to $7.41 \pm 0.01(P<$ 0.01 ) in group $A$ babies was associated with a decrease in $\mathrm{PCO}_{2}$ from $44.2 \pm 1.0$ to $38.9 \pm 1.4 \mathrm{~mm} \mathrm{Hg}$. Values remained unchanged with age in group $B$ babies. After institution of calcium supplementation, base excess values differed transiently between groups (at age 5 weeks, group $A-\mathbf{0 . 1 6} \pm \mathbf{0 . 5 6} \mathbf{~ m E q} /$ liter, group $B$ $-2.23 \pm 0.76 \mathrm{mEq} /$ liter $; P<\mathbf{0 . 0 5}$ ).

Mean ionic calcium values remained unchanged in group $A(2.37$ $\pm 0.06 \mathrm{mEq} /$ liter), but increased slightly from $2.42 \pm 0.06$ to 2.57 $\pm 0.04 \mathbf{m E q} /$ liter in group $B(P<\mathbf{0 . 0 5})$. Total plasma calcium differed transiently between groups after calcium supplementation had started in group $B$ (Group $A, \mathbf{4 . 5 3} \pm \mathbf{0 . 0 8} \mathbf{~ m E q} /$ liter; group $B$, $4.82 \pm 0.12 \mathrm{mEq} / \mathrm{liter} ; P<0.05)$, and plasma $\mathrm{Mg}$ and $\mathrm{P}$ levels were lower in group $B$ babies than in group $A$ babies $(P<0.01)$. All infants remained somewhat hypoproteinemic throughout the study; mean values of plasma total protein averaged $4.5 \mathrm{~g} / 100 \mathrm{ml}$.
Mean urinary excretion rates of calcium initially were 0.17 $\mathrm{mEq} / \mathrm{kg} / 24 \mathrm{hr}$ in group $A$ babies and $0.18 \mathrm{mEq} / \mathrm{kg} / 24 \mathrm{hr}$ in group $B$ infants, and no increase was seen with calcium supplementation.

Fecal excretion of calcium (percentage of intake) decreased from $70 \%$ to $33 \%$ in group $B$ babies after calcium supplementation. Calcium retention rates $(\mathrm{mEq} / \mathrm{kg} / 24 \mathrm{hr})$ were similar in both groups initially but increased subsequently in group $B$ from 1.20 to $7.33 \mathrm{mEq} / \mathrm{kg} / 24 \mathrm{hr}$ and were 3 times as high in group $B$ than in group $A$ during the second and third balances.

Urinary phosphorus excretion was initially similar in both groups (group $A, 28.4 \pm 2.2 \mathrm{mg} / \mathbf{k g} / 24 \mathrm{hr} ;$ group $B, 32.4 \pm 5.5 \mathrm{mg} / \mathrm{kg} / 24$ hr), but decreased to half this value in infants of group $B$ after calcium supplementation had started $(P<\mathbf{0 . 0 2})$.

$G$ roup $B$ infants showed a higher percentage fecal fat excretion than group $A$ infants during the second and third balance.

In 9 of 10 paired radiographs of the knee and tibia group $B$ infants showed better defined bone texture and/or wider cortices than did group $A$ infants.

We suggest that prevention of the "bone disease of very low birth weight (VLBW) infants" may be accomplished by suitable calcium supplements.

\section{Speculation}

As a consequence of their special requirements and the unavailability of appropriately constituted infant formulas, infants born very prematurely fail to achieve intrauterine accretion rates for many minerals. Postnatal growth may also be jeopardized. We believe that for optimal postnatal growth infants born very prematurely require sufficient nutrients to parallel intrauterine accretion rates.

The VLBW infant, who is deprived of elements which normally 